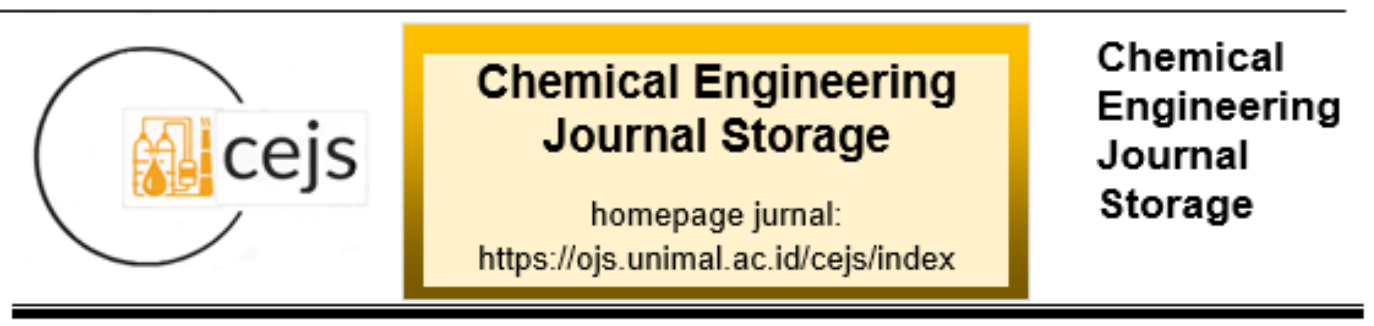

\title{
PEMBUATAN KOMPOSIT HYBRID DARI SERBUK BENTONIT DAN PELEPAH PISANG DENGAN PENGUAT MATRIK POLYSTERENA
}

\author{
Nurul Safriani ${ }^{1}$, Eddy Kurniawan ${ }^{1}$, Syamsul Bahri ${ }^{1}{ }_{\text {,Ishak }}{ }^{1}$,Jalaluddin $^{1}$ \\ ${ }^{1}$ Jurusan Teknik Kimia, Fakultas Teknik, Universitas Malikussaleh \\ Kampus Utama Cot Teungku Nie Reuleut, Muara Batu, Aceh Utara - 24355 \\ Korespondensi:HP: 08126965724, e-mail: eddy.kurniawan@unimal.ac.id
}

\begin{abstract}
Abstrak
Komposit pada umumnya terdiri dari dua unsur, yaitu serat (fiber) sebagai bahan pengisi dan bahan pengikat serat-serat tersebut yang dikenal dengan matriks. Pembuatan komposit hybrid menggunakan pelepah pisang,serbuk bentonit, dan polystirena menggunakan metode Hand lay up. Pengujian yang dilakukan yaitu: Analisa FTIR untuk mengtahui gugus fungsi pada pelepah pisang dan serbuk bentonit dalam komposit. Untuk perbandingan komposisi pelepah pisang : serbuk bentonit $=(0 \%: 50 \%) ;(30 \%: 20 \%) ;(20 \%: 30 \%) ; \quad(50 \%: 0 \%)$. Volume Asam Akrilat: $2 \mathrm{ml}$, Serbuk bentoni, Pelepah pisang, Toluena $25 \mathrm{ml}$, Polistirena, Ukuran cetakan. Uji Tarik, Uji FTIR, Analisa Daya Serap Air. Komposit yang memiliki nilai uji tarik maksimum diperoleh pada variasi 30\%:20\% yaitu $8.43 \%$ Mpa. Dan hasil tersebut belum mencapai SNI. Komposit yang memiliki nilai analisa daya serap air maksimum diperoleh pada variasi 30\%:20\% yaitu 8.43\%. Semakin bertambahnya komposisi filler antara serbuk bentonit dan pelepah pisang maka dapat meningkatkan nilai uji tarik dan analisa daya serap air. Komposisi filler yaitu antara serbuk bentonit dan pelepah pisang sama sama memiliki peranan penting saat pembuatan komposit maupun saat dilakukan pengujian komposit.
\end{abstract}

Kata kunci: Asam akrilat, Komposit, Polysterena, Pelepah pisang, Serbuk bentonit.

\section{Pendahuluan}

Berbagai jenis bahan polimer bisa dipergunakan dalam aspek kehidupan, seperti memanfaatkan bahan yang berasal dari tumbuhan atau serat organic. Kombinasi ini biasa dikenal sebagai komposid hybrid. Komposit adalah suatu jenis bahan baru hasil rekayasa yang terdiri dari dua atau lebih bahan dimana sifat masing-masing bahan berbeda satu sama lainnya baik itu sifat kimia maupun sifat 
fisikanya dan tetap terpisah dalam hasil akhir bahan tersebut. Gabungan dua material tersebut mempunyai fungsi masing-masing. Matrik berfungsi sebagai pengikat sedangkan serat berfungsi sebagai penguat, sehingga komposit tersebut menghasilkan material baru yang ringan dan kuat (Surono,U. B \& Sukoco, 2016). Komposit memiliki unsur utama yaitu serat, sedangkan untuk bahan pengikatnya digunakan polimer yang mudah dibentuk dan memliki daya pengikat yang tinggi (Silvia et al., 2015). Sedangkan komposit hybrid adalah suatu gabungan dari beberapa lapisan atau serat yang searah dan disusun dengan jumlah tertentu, optimalnya komposit hybrid merupakan suatu peluang yang baik untuk diteliti lebih lanjut pada pemakaian aplikasi struktur komposit secara lebih luas (Yudhanto, F., \& Sudarisman, 2016).

Pelepah pisang merupakan bahan berpori yang dapat digunakan sebagai aplikasi dalam pembuatan papan serat komposit atau bisa juga sebagai pembuatan vinyl lantai kayu. Pelepah pisang hanya berisi serabut-serabut yang lunak, sehingga tidak dapat digunakan sebagai bangunan dan lain-lain. Nambun batang pisang dapat dimanfaatkan sebagai sayur. Pelepah pisang juga memiliki jaringan selular dengan pori-pori yang saling berhubungan, serta apa bila telah dikeringkan akan menjadi padat hingga menghasilkan suatu bahan yang memiliki daya serap yang cukup bagus (Khotimah et al., 2014).

Pelepah pisang banyak dimanfaatkan masyarakat, terutama bagian yang mengandung serat. Setelah dikelupas setiap lembar sering dimanfaatkan sebagai pembungku suntuk bibit tanaman sayur dan setelah dikeringkan digunakan untuk tali pada pengolahan tembakau, dan dapat pula digunakan untuk kompos. batang pisang sebagai limbah dapat dimafaatkan menjadi sumber seratagam rmempunyai nilai ekonomis. Menyatakan bahwa perbandingan bobot segar antara batang, daun, dan pisang berturut-turut 63, 14, dan 23\%. Batang pisang memiliki bobot jenis0,29 $\mathrm{g} / \mathrm{cm}^{3}$ dengan ukuran Panjang serat 4,20-5,46 mm dan kandungan lignin $33,51 \%$ (Saputra et al., 2018). 
Bentonit dikenali sebagai tanah liat, merupakan jenis mineral halus, berbentuk kepingan, komposisi makro dari bentonit $\mathrm{SiO} 2$ 50,03\% (Sebayang, 2010).

Bentonit merupakan tanah yang membetuk masssa lengket ketika dicampur dengan air. Dalam keadaan basah massa tersebut dapat dibentuk, namun dalam keadaan kering massa tersebut menjadi keras, rapuh dan mempertahankan bentuknya. Lebih lanjut, jika dipanaskan, bentonit akan mengeras dan tidak dapat berinteraksi lagi dengan air. Ukuran partikel bentonit sangat kecil dan umumnya bergantung pada komposisi spesifik. Partikel-partikel utama bentonit memiliki ukuran kurang dari satu micrometer. Dengan ukuran yang kecil tersebut, bentonit memiliki luas permukaan spesifik (luas permukaan per satuan massa) yang besar. (Abdullah,2009). Silika termasuk bahan pengisi penguat sehingga dengan melakukan komposit menggunakan bentonit diharapkan mampu meningkatkan sifat fisik barang jadi karet, sehingga dapat meningkatkan kekerasan kekuatan tarik. (Alfa, 2005).

\section{Bahan dan Metode}

Pembuatan komposit hybrid dari matrik polysterena dilakukan dengan metode hand lay up. Keuntungan yang dimiliki oleh metode hand lay up merupakan proses metode terbuka dari proses fabrikasi komposit. Matrik yang digunakan yaitu polysterena pemilihan polysterena sebagai matrik dirdasarkan pada pengolahan limbah yang dimana mudah didapatkan dilingkungan sekitar. Polysterena merupakan bahan polimer non polar berbentuk padatan. Sehingga sebelum digunakan pada pembuatan komposit harus dilarutkan menggunakan pelarut non polar yang mudah menguap. Untuk melarutkan polisterena digunakan pelarut toluene, dan merupakan larutan dengan memiliki nilai parameter yang hampir sama. Toluena juga merupakan senyawa non polar maka dapat larut dengan baik pada pelarut non polar. Proses awal pembuatan komposit hybrid adalah persiapan bahan baku yaitu pelepah pisang dan serbuk bentonit, polysterena, asam akilat, dan toluena. Pelepah pisang dibersihkan lalu dipotong 
menjadi bagian yang lebih kecil kemudian dicampur dengan serbuk bentonik memiliki perbedaan pada pembuatan papan komposit, yaitu $0 \%$.

0\%: 50\%, 20\%: 30\%, 30\% : 20\%, dan 50\% : 0\%. Pada komposisi tersebut dilakukan satu perlakuan dimana sebanyak 3 gram polysterena dilarutkan menggunakan $25 \mathrm{ml}$ toluena, lalu menambahkan asam akilat sesuai variasi. Hal ini bertujuan untuk melihat perubahan asam akrilat dalam proses pembuatan komposit hybrid.

Pada penelitian ini setiap komposit di diamkan dalam suhu kamar selama 1 minggu karakteristik yang di uji pada penelitian ini adalah uji tarik dan uji daya serap air. Pada penelitian ini akan dilihat pengaruh komposisi pelepah pisang dan serbuk bentonit pada pembuatan komposit.

Penelitian ini terdiri dari delapan tahap yaitu Polistirena/gabus elektronik yang disiapkan dan ditimbang sebanyak $20 \mathrm{gr}$, dilarutkan polistiren yang telah ditimbang dengan menggunakan $25 \mathrm{ml}$ touluen, ditambahkan serbuk bentonit dan pelepah pisang yang sudah ditimbang sesuai variabel, ke dalam larutan polistiren dan ditambahkan asam akrilat, aduk campuran menggunakan magnetic stirer sampai bahan-bahannya tercampur merata dan sempurna, campuran tersebut adalah komposit yang siap dicetak, Kemudian campuran dimasukkan ke dalam cetakan dengan ukuran yang telah dilapisi aluminium foil dan ditutup. Dengan ukuran cetakan : $(11 \mathrm{~cm}$ x 2,5 $\mathrm{cm}$ x 0,5 cm) seperti pada gambar 1, Komposit yang sudah dicetak, dikeringkan dengan suhu ruang sampai kering selama (7 hari), komposit yang sudah kering diambil sampelnya untuk dilakukan pengujian.

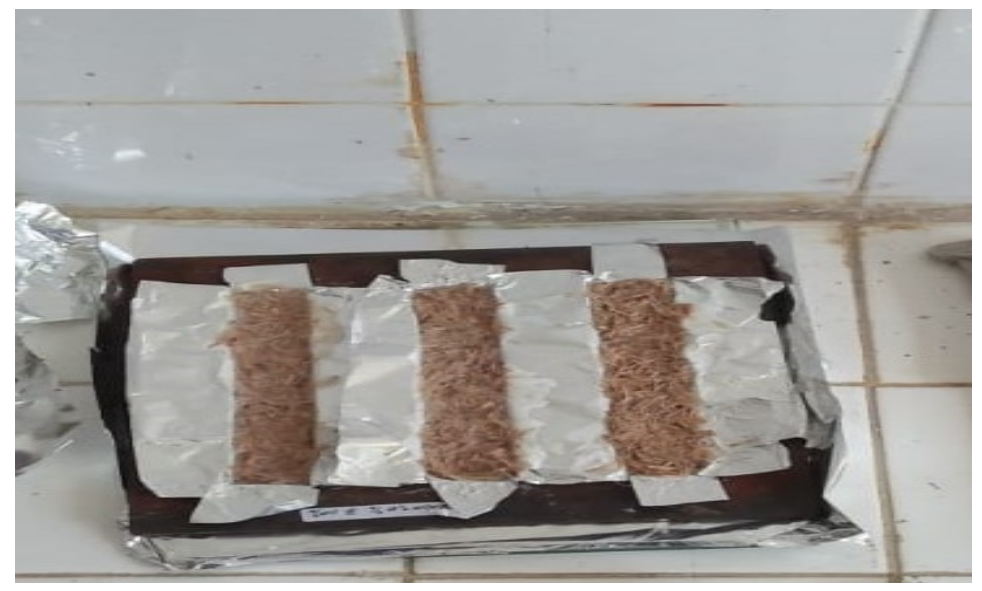

Gambar 1. Pencetakan komposit 


\section{Hasil dan Diskusi}

Komposit yang dihasilkan pengujian uji tarik, Analisa FTIR, dan Analisa daya serap air. Hasil pengujian tarik, dan Analisa daya serap air pengujian data ditunjukkan pada tabel 4.1. Hasil untuk data Analisa FTIR pada tabel 3.1

Tabel 3.1 Hasil analisa komposit pada pengujian tarik dan daya serap air pada komposit.

\begin{tabular}{|c|c|c|c|c|}
\hline Polysterena & $\begin{array}{c}\text { Pelepah } \\
\text { Pisang }\end{array}$ & $\begin{array}{c}\text { Serbuk } \\
\text { Bentonit }\end{array}$ & $\begin{array}{c}\text { Uji Tarik } \\
\text { (mpa) }\end{array}$ & Daya Serap Air \\
\hline \multirow{3}{*}{$50 \%$} & $0 \%$ & $50 \%$ & 0.5 & 4.26 \\
\cline { 2 - 5 } & $30 \%$ & $20 \%$ & 0.9 & 8.43 \\
\cline { 2 - 5 } & $20 \%$ & $30 \%$ & 0.7 & 8.14 \\
\cline { 2 - 5 } & $50 \%$ & $0 \%$ & 0.6 & 8.21 \\
\hline
\end{tabular}

\subsection{Pengaruh Perbandingan Mattrik Dan Filler Terhadap Uji Tarik}

Pengujian tarik merupakan jenis pengujian yang dilakukan dengan melakukan penarikan terhadap suatu bahan sampai tersebut putus atau patah. Komposit yang telah jadi kemudian di uji keuatan mekaniknya yaitu kekuatan tariknya dengan menggunakan mesin uji tarik. Pengujian ini dilakukan muntuk mengetahui besarnya kekuatan tarik dari bahan komposit. Pengujian dilakukan dengan mein uji (Rahmat Iskandar Fajri, 2013) 


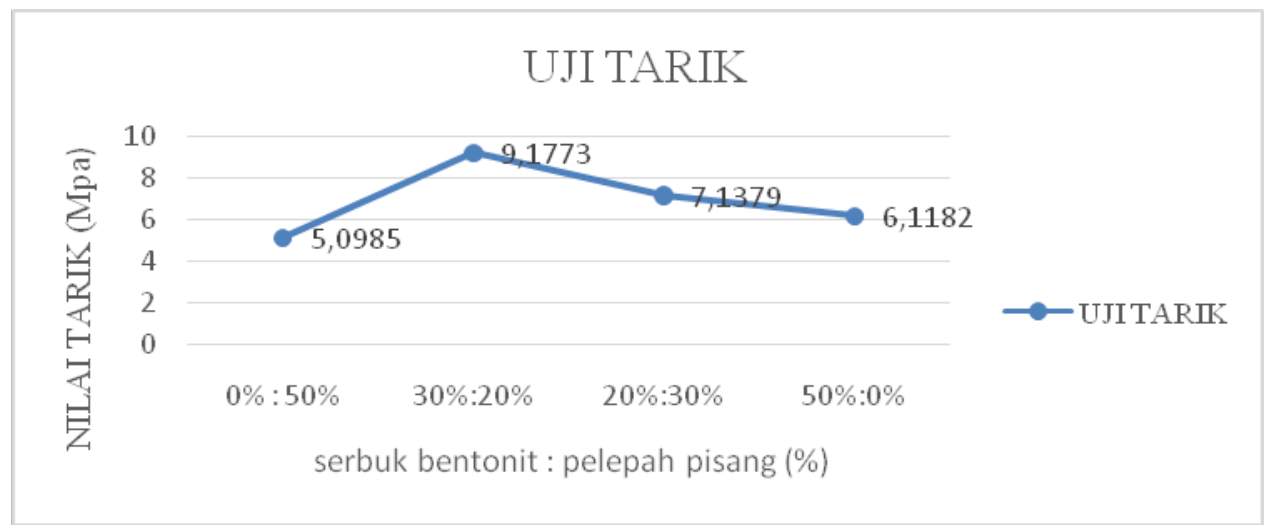

Gambar 4.1 pengaruh perbandingan variasi pelepah pisang dan serbuk bentonit tehadap uji tarik

( Sumber Data: Alat pengujian MTS EM ASTM D638 TENSION 1086)

Berdasarkan data dari tabel 4.1 di peroleh gambar grafik 4.1 perbandingan variasi dan filler yaitu 50\%:50\% terhdap variasi volume filler pada matrik tetap 50\%.. Dapat diketahui dari grafik bahwa kenaikan dan penurunan nilai uji tarik pada tiap variasi filler, nilai uji tertinggi di dapatkan pada volume filler yaitu $30 \%$ pelepah pisang dan serbuk bentonit $20 \%$ dengan asam akrilat $2 \mathrm{ml}$ yaitu 9.1773 Mpa. Hal ini dikarenakan pengaruh banyak pelepah pisang yang memiliki nilai daya tarik yang tinggi, dimana dalam variasi tersebut mampu mengikat mattrik dan filler dengan baik. Sehingga komposisi dalam komposit tersebut semakin baik. Dan nilai terendah untuk uji tajik terdapat pada variasi $50 \%$ serbuk bentonit dan 0\% pelepah pisang yaitu 5.0985 Mpa. Hal ini dikarenakan bentonit memiliki nilai tarik yang rapuh.

\subsection{Analisa Daya Serap Air}

Analisa daya serap air adalah suatu teknik untuk mengetahui seberapa besar daya serap air yang bisa diperoleh komposit disaat dilakukan perendaman dan pengeringan. Pengujian daya serap air dilakukan untuk mengetahui penambahan massa setelah perlakuan perendaman sampel uji selama 24 jam di dalam air. Sampel uji ditimbang sebagai berat awal dan ditimbang sebagai berat akhir setelah dilakukan perendaman. (Luthfi Hakim \& fauizi, 2005) 


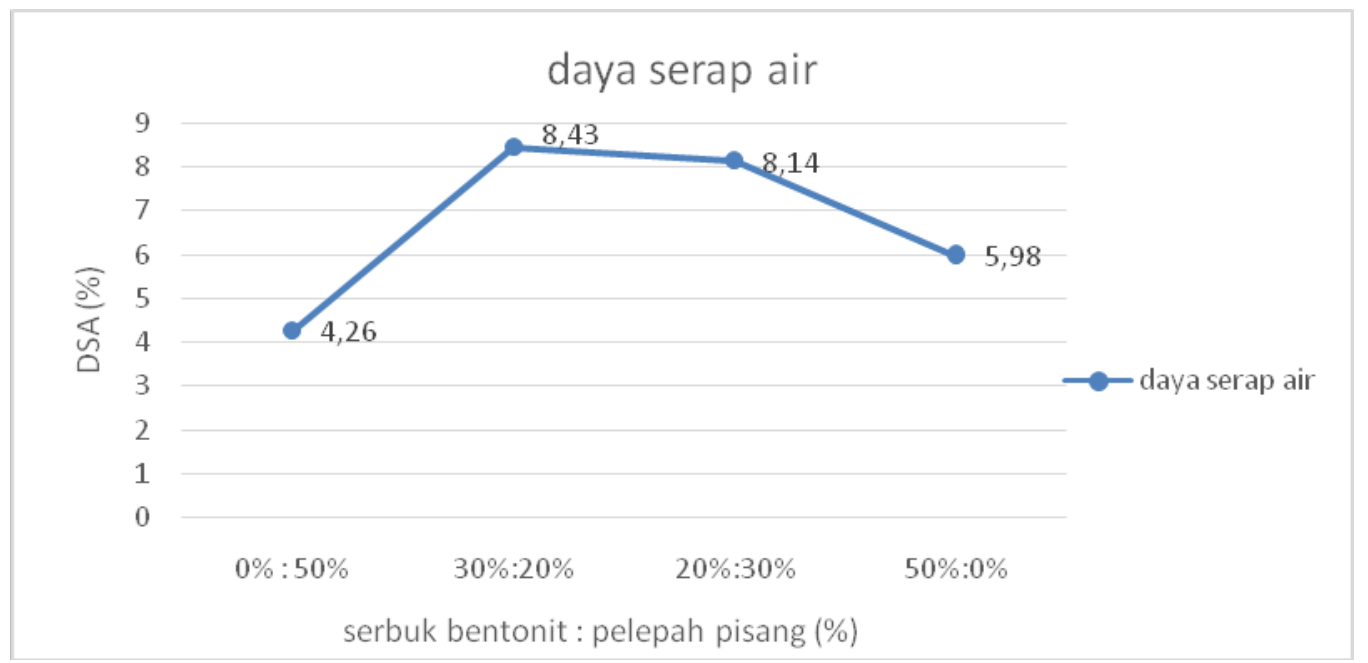

Gambar 4.2 Pengaruh daya serap air terhadap perbandingan filler ( Sumber Data: tabel 4.1)

Nilai daya serap air sampel uji papan komposit setelah sampel uji papan komposit dilakukan perendaman selama 24 jam berkisar $4.26 \%$ sampai $8.43 \%$ nilai rata-rata daya serap air tertinggi setelah perendaman selama 24 jam terdapat pada papan dengan perbandingan pada 30\% pelepah pisang dan $20 \%$ serbuk bentonit sebesar $8.43 \%$, sedangkan nilai daya serat air yang paling rendah terdapat pada papan dengan perbandingan pelepah pisang $0 \%$ dan serbuk bentonit $50 \%$ sebesar $4.26 \%$.

Nilai rata-rata hasil pengujian daya serap air papan partikel setelah perendaman selama 24 jam dapat dilihat pada gambar 4.2 yang menunjukan bahwa tingginya nilai rata-rata daya serap air papan komposit yang dihasilkan pada perendaman 24 jam memiliki nilai daya serap air yang relative tinggi. Hal ini diakibatkan pelepah pisang dan serbuk bentonit mempunyai berat jenis yang tinggi dimana rongga selnya yang kecil tidak mudah menyerap air dalam kapasitas besar. Penggunaan perekat polysterena bertujuan untuk mereduksi penyerapan air pada komposit. Polysterena yang bersifat plastik dapat mengurangi penyerapan air.

\subsection{Analisa Gugus Fungsi FTIR}

FTIR merupakan salah satu yang membedakannya adalah pengembangan pada sistim optiknya sebelum berkas sinar infra merah. Bila radiasi infa merah 
yang kisaran energinya sesuai dengan frekuensi vibrasi rentang (str etching) dan vibrasi bengkokan instrument yang digunakan untuk mengetahui gugus fungsi senyawa kimia, atau gugus fungi yang terdapat dalam sampel. Pada dasarnya spektrofotometer FTIR (fourier trasform infra red) adalah sama dengan Spektrofotometer IR disperse, (bending) dari ikatan kovalen dalam kebanyakan molekul dilewatkan dalam suatu cuplikan, maka molekul-molekul akan menyerap energy tersebut dan terjadi transisi diatara tingkat energy vibrasidasi dan tingkat vibrasi tereksitasi (Hendayana, dkk, 1994). Namun demikian tidak semua ikatan dalam molekul dapat menyerap energy infra merah meskipun mempunyai frekuasi radiasi sesuai dengan gerakan ikatan. Hanya ikatan yang mempunyai momen dipol dapat menyerap radiasi infa merah. (Sastrohamidjojo, 1992)

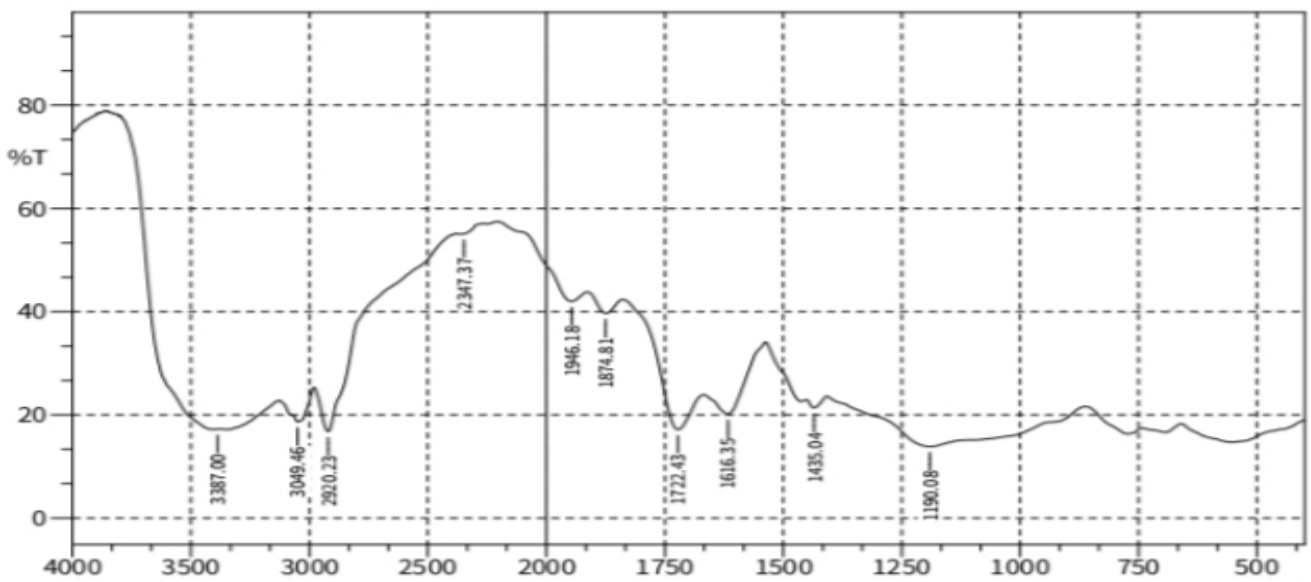

Gambar 4.3 grafik dari pelepah pisang dan serbuk bentonit pada komposit

Berdasarkan pada gambar 4.3 jika diamati dari bilangan gelombang yang diperoleh dapat dijelaskan bahwa Spetra komposit pelepah pisang dan serbuk bentonit munculnya puncak serapan pada bilangan gelombang $3387.00 \mathrm{~cm}^{-1}$ yang merupakan gugus $\mathrm{O}-\mathrm{H}$ yang menunjukkan terbentuknya kelompok ikatan hidrogen dalam satu kelompok gugus hidroksil. Pita serapan pada bilangan gelombang $3049.46 \mathrm{~cm}^{-1}$ merupakan gugus $\mathrm{C}-\mathrm{H}$ menunjukkan adanya gugus karboksil. Pada puncak serapan $1616.35 \mathrm{~cm}^{-1}$ menunjukkan adanya gugus $\mathrm{C}=\mathrm{C}$ dari alkuna pada aderah serapan 1610-1680. Berdasarkan identifikasi tersebut terbukti bahwa spetra komposit pelepah pisang dan serbuk bentonit yang di hasilkan memiliki serapan pada bilangan yang hampir sama. 


\section{Simpulan dan Saran}

Komposit yang memiliki nilai tarik maksimun diperoleh dengan variasi pelepah pisang dan serbuk bentonit 30\%: 20\% dengan nilai 9.1773 Mpa Hal ini dikarenakan pengaruh banyak pelepah pisang yang memiliki nilai daya tarik yang tinggi, dimana dalam variasi tersebut mampu mengikat mattrik dan filler dengan baik. Sehingga komposisi dalam komposit tersebut semakin baik. dan yang paling renda pad 0\% : 50\% dengan nilai 5.0985 Mpa hal ini dikarenakan bentonit memiliki nilai tarik yang rapuh. Komposit yang memiliki nilai daya serap air yang paling rendah diperoleh dengan variasi $0 \%$ pelepah pisang dan serbuk bentonit $50 \%$ dengan nilai $4.26 \%$. Hal ini diakibatkan pelepah pisang dan serbuk bentonit mempunyai berat jenis yang tinggi dimana rongga selnya yang kecil tidak mudah menyerap air dalam kapasitas besar komposit yang baik adalah komposit yang memiliki daya serap air yang rendah. Semakin bertambahnya komposisi filler antara pelepah pisang dan serbuk bentonit maka dapat meningkatkan nilai uji tarik dan pada analisa daya serap air memiliki daya serap air yang tinggi dikarenakan pelepah pisang memiliki nilai daya tarik yang baik untuk pembuatan komposit.

Pastikan bahan baku yang dipilih dalam pembuatan tidak mudah rapuh dan patah. Pastikan tidak menggunakan toluena yang sudah lama atau warnanya berupah menjadi kuning karena dikhawatirkan tidak akan bisa melarutkan polystirena 
Nurul Safriani / Chemical Engineering Journal Storage 1 :2 (Oktober 2021) 35-45

\section{Daftar Pustaka}

1. Adiguna,A.(2019). Desain Marka Jalan Dari Beton Dengan Replacement System. Jurnal Deformasi, 4(1), 44.

https://doi.org/10.31851/deformasi.v4i1.2973

2. Abdullah, Muhammad., dkk. (2009). Sintesis Keramik Berbasis Komposit Clay-Karbon dan Karakterisasi Kekuatan Mekaniknya. Jurnal Nanosains \& Nanoteknologi ISSN 1979- 0880 Vol. 2 No.2.

3. Alfa, A.A. (2005). Bahan Kimia untuk Kompon Karet. Kursus Teknologi Barang Jadi Karet Padat. Balai Penelitian Teknologi Karet Bogor. Bogor.

4. Asroni, \& Handono, S. D. (2018). Kaji Eksperimen Variasi Jenis Serat Batang Pisang. Universitas Myhammadiyah Metro, 7(2), 214-222.

5. Khotimah, K., Susilawati, \& Soeprianto, H. (2014). Komposit Serat Batang Pisang ( SBP ) - Epoksi Sebagai Bahan Penyerap Bunyi. 2(4), 322-326.

6. Noor, a. A. (2019). Pengaruh Presentase Alkalisasi Naoh Terhadap Kekuatan Tarik Material Komposit Serat Daun Nanas Polyester Dengan Metode Vacuum Infusion Skripsi.

7. Ramdhani, a. J. (2014). Asep Jaka Ramdhani, 2014 Adsorpsi Batubara Peringkat Rendah Termodifikasi Hidrogen Peroksida Terhadap Ion Logam Kadmium Dan Besi Universitas Pendidikan Indonesia | Repository.Upi.Edu Perpustakaan.Upi.Edu.

8. Rakhmawati, I., \& Kurniawan, C. (2019). Indonesian Journal of Chemical Science Pengaruh Konsentrasi Metilenbisakrilamida dalam Sintesis Komposit Poli (Asam Akrilat ) -Kaolin dan Pengujiannya sebagai Superabsorben. Indonesian Journal of Chemical Science, 8(2), 1-12.

9. Samlawi, A. K., Arifin, Y. F., \& Permana, P. Y. (2018). PEMBUATAN DAN KARAKTERISASI MATERIAL KOMPOSIT SERAT IJUK ( Arenga pinnata ) SEBAGAI BAHAN BAKU COVER BODY SEPEDA MOTOR Preparation and Characterization of Composite Materials of Ijuk Fiber (Arenga pinnata ) as a Motorcycle Body Cover Raw Material. Prosiding Seminar Nasional Lingkungan Lahan Basah Teknik Universitas Lambung Mangkurat, 3(2), 380-383.

9. Silvia, Castiqliana, \& Halimatuddahliana. (2015). Pengujian Kekuatan Tarik Dan Kekuatan Lentur Komposit Hibrid Plastik Bekas Kemasan Gelas Jenis Polipropilena/ Serbuk Kayu Kelapa Termodifikasi/Serbuk Serat Kaca Tipe E. Jurnal Teknik Kimia USU, 4(3), 1-5. 
https://doi.org/10.32734/jtk.v4i3.1473

10. Surono, U. B., \& Sukoco. (2016). Analisa Sifat Fisis dan Mekanis Komposit Serat Ijuk Dengan Bahan Matrik Poliester. Prosiding Seminar Nasional XI “Rekayasa Teknologi Industri Dan Informasi, (11), 298-303.

11. Wardani, f. K. (2021). Kekuatan Impak Resin Akrilik Polimerisasi Panas Setelah Penambahan Universitas Sumatera Utara.

12. Warsi. (2004). Sintesis 4 - Hidroksi - 3 - Klorobenzaldehid Dari P Hidroksibenzaldehid Dan Gas Cl 2 Synthesis Of 3 - Chloro - 4 Hydroxybenzaldehyde From P - Hydroxybenzaldehyde And Cl 2 Gas.

13. Yudhanto, F., \& Sudarisman. (2016). Karakterisasi Kekuatan Tarik Komposit Hybrid Lamina Serat Anyam Sisal Dan Gelas Diperkuat Polyester Characterization of Tensile Strength Laminate Hybrid Composite of Woven Sisal F ... Karakterisasi Kekuatan Tarik Komposit Hybrid Lamina Serat 